\title{
Corrosion Characteristics of Aluminum in Highly Diluted Ammonia Solution
}

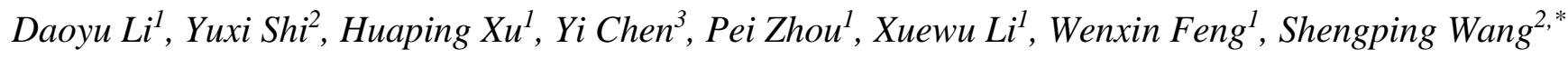 \\ ${ }^{1}$ Guiyang Bureau, Extra High Voltage Power Transmission Company, China Southern Power Grid \\ (CSG), Guiyang 550081, China \\ ${ }^{2}$ Faculty of Material Science and Chemistry, China University of Geosciences, Wuhan 430074, China \\ ${ }^{3}$ Operational Technology Department, Extra High Voltage Power Transmission Company, China \\ Southern Power Grid (CSG), Guangzhou 510663, China \\ *E-mail: spwang@cug.edu.cn
}

doi: $10.20964 / 2018.10 .61$

Received: 27 June 2018 / Accepted: 8 August 2018 / Published: 1 September 2018

\begin{abstract}
Aluminum radiators working with deionized water in high voltage direct current (HVDC) transmission systems were severely corroded. In this paper, the corrosion behavior of aluminum from an aluminum radiator in HVDC in highly diluted ammonia solution was studied, focusing to reduce the corrosion of aluminum in nearly neutral aqueous solution. The surface of the aluminum electrode was covered with $\mathrm{Al}(\mathrm{OH})_{3}$ and/or $\mathrm{Al}_{2} \mathrm{O}_{3}$, and the corrosion products could reduce further corrosion. It was found that an aluminum electrode in $0.84 \mu \mathrm{mol} \mathrm{L}^{-1}$ ammonia solution had the lowest corrosion rate, and its mechanisms for good corrosion resistance were given. This technology can be used for material anticorrosion in heatexchange equipment with cooling water.
\end{abstract}

Keywords: Aluminum, Corrosion, Ammonia solution, Radiator, Thyristor, HVDC

\section{FULL TEXT}

(C) 2018 The Authors. Published by ESG (www.electrochemsci.org). This article is an open access article distributed under the terms and conditions of the Creative Commons Attribution license (http://creativecommons.org/licenses/by/4.0/). 